\title{
FILOZOFIA A NAUKA W KONTEKŚCIE LABORATORYJNEGO STYLU BADAŃ NAUKOWYCH ROBERTA BOYLE'A
}

R. Kazibut, Filozofia przyrody i przyrodoznawstwa Roberta Boyle'a. Filozoficzna geneza nauki laboratoryjnej, Poznań: Wydawnictwo Naukowe UAM 2019, ss. 205, ISBN: 978-83-232-3430-2

\section{Abstract \\ Philosophy versus SCIENCE In THE CONTEXT OF ROBERT BOYLE's LABORATORY STYLE OF SCIENTIFIC RESEARCH}

This is a review of Radosław Kazibut's book Filozofia przyrody i przyrodoznawstwa Roberta Boyle'a. Filozoficzna geneza nauki laboratoryjnej (Robert Boyle's Philosophy of Nature and Natural Science: The Philosophical Origins of Laboratory Research), in which I highlight the strengths and weaknesses of the proposed approach. On the one hand, I appreciate the author's effort to examine the origin of the laboratory style of research, which is found in Boyle's studies, as a basis for a novel approach to the problem of the relationship between philosophy and science. On the other hand, I am critical of the fact that the author has overlooked several issues relating to the subject matter which, in the context of the topics addressed in the book, should be recognized as relevant. The characterization of the laboratory sciences presented in the book is too selective as it ignores the problem of the undesirable products of the laboratory sciences as well as their increasingly practical character.

Keywords: Robert Boyle, philosophy of nature and natural science, experimentalism, laboratory science, Radosław Kazibut

Monografia Radosława Kazibuta pt. Filozofia przyrody i przyrodoznawstwa Roberta Boyle'a. Filozoficzna geneza nauki laboratoryjnej składa się z czterech rozdziałów. Opatrzona jest wprowadzeniem, w którym autor przed-

* Studium Nauk Humanistycznych i Społecznych, Politechnika Wrocławska, Wybrzeże Wyspiańskiego 27, 50-370 Wrocław, e-mail: m.sikora@pwr.edu.pl, ORCID: https:// orcid.org/oooo-0002-9451-8278. 
stawia swoje główne zamierzenia badawcze, zaproponowaną przez siebie strukturę argumentacji oraz zarys stanu badań nad intelektualnym dorobkiem Roberta Boyle'a. Rozprawę zamyka zbudowane w sposób syntetyczny zakończenie. Całość uzupełniona jest bibliografią, skorowidzem nazwisk i skorowidzem rzeczowym oraz krótkim streszczeniem w języku angielskim. Tematem książki jest analiza filozoficznego i naukowego dorobku Roberta Boyle'a (1627-1691), wybitnego brytyjskiego uczonego oraz współtwórcy Królewskiego Towarzystwa Londyńskiego dla Doskonalenia Wiedzy Przyrodniczej (Royal Society). Po omówieniu prac Boyle’a autor stawia tezę, że przedstawiona w nich

filozofia przyrody i przyrodoznawstwa odegrały główną rolę w kształtowaniu się współczesnego filozoficzno-metodologicznego zaplecza praktyki badawczej nauki laboratoryjnej. Bez wątpienia od powstania laboratoryjnego stylu Boyle'a nauka laboratoryjna uległa transformacji i rewolucyjnym przekształceniom. Laboratorium Boyle’a i współczesne laboratorium właściwie pod żadnym względem nie są porównywalne, jednakże od XVII wieku nauka laboratoryjna oparta jest na względnie stałym i charakterystycznym dla niej zespole założeń. Można wykazać, że, między innymi, są to filozoficzne założenia o prymacie eksperymentowania w laboratoryjnym przyrodoznawstwie i epistemicznym jego charakterze. A także o tym, iż proces powstawania tej praktyki badawczej był zdeterminowany dążeniem naukowców do doskonalenia instrumentarium i standaryzacji badań (Kazibut 2019: 8).

Kazibut skupia się zatem na rozpoznaniu i scharakteryzowaniu wpływu, który Boyle wywarł na proces kształtowania się nowożytnego i współczesnego laboratoryjnego stylu badań naukowych. Realizując ten cel, odwołuje się zarówno do wybranych pism samego Boyle’a, jak i znawców jego twórczości oraz do najnowszych ustaleń historyków nauki.

W pierwszym rozdziale pracy Filozofia przyrody, filozofia naturalna i filozofia eksperymentu Roberta Boyle’a omówione zostały filozoficzne poglądy Boyle'a, nazwanego „ojcem chemii analitycznej”. Jego rozprawa Sceptical Chymist z 1661 roku jest, jak pisze Kazibut, „symbolicznym «słupem Herkulesa», za którym rozpoczął się proces ksztaltowania nie tylko nowożytnej chemii, ale także laboratoryjnej praktyki badawczej” (Kazibut 2019: 19). Pierwszy rozdział składa się z trzech podrozdziałów, które dotyczą kolejno: 1) pytania: natura czy przyroda, 2) zadań i celów poznania naukowego oraz 3) eksperymentalizmu laboratoryjnego Boyle'a. Przywołane w porządku historycznym rozważania nad naturą i przyrodą Kazibut wykorzystuje do przedstawienia współczesnych ustaleń na temat powstawania różnych systemów filozoficzno-przyrodniczych. W tym celu omówione zostają następujące zagadnienia: korpuskularystyczny i mechanistyczny obraz świata, Bóg jako sprawcza i celowa przyczyna w świecie przyrody oraz filozoficzne ujęcie świata przyrody. Odnosząc się do tych zagadnień, Kazibut stwierdza, że duży 
wpływ na rozwój badawczej praktyki laboratoryjnej Boyle’a miały przyjmowane przez niego założenia filozoficzne. Ich akceptacja doprowadziła do tego, że Boyle w swych analizach mógł przejść od rozważań nad naturą do rozważań nad przyrodą, co w konsekwencji doprowadziło do zniesienia opozycji naturalne - sztuczne oraz reorientacji w zakresie dociekań filozoficznych, które z tradycyjnie ujmowanej filozofii przyrody przeobrazily się w filozofię przyrodoznawstwa:

Rozwój laboratoryjnego stylu eksperymentowania i konceptualizacja korpuskularystycznej teorii materii wynikał[y] z przemian dokonanych, między innymi za sprawą Boyle'a, w sposobie uprawiania filozoficznej refleksji nad przyrodą. Siedemnastowieczna rewolucja naukowa była zasadniczo związana z dokonaniem zmiany perspektywy przedmiotu analizy w obszarze rozważań filozoficznych (Kazibut 2019: 35).

W podrozdziale na temat zadań i celów poznania naukowego Kazibut omawia: i) Baconowski program historii naturalnej, ii) Boyle'a historię naturalną i filozofię naturalną oraz iii) prometejskie ambicje nauki. Porównując reprezentowany przez Boyle'a i Bacona sposób uprawiania nauki, Kazibut pisze, że mimo niewątpliwych różnic między tymi dwoma badaczami obaj zgodnie podkreślają użytkową funkcję poznania naukowego. Ponadto obu można traktować jako twórców manifestu nowej nauki, w której akcentuje się rolę badacza i praktyczny wymiar działalności naukowej.

Podrozdział poświęcony eksperymentalizmowi laboratoryjnemu Boyle'a składa się z rozważań na temat: i) filozoficznych założeń eksperymentalizmu, ii) zasady intersubiektywnej sprawdzalności i komunikowalności wiedzy naukowej w eksperymentalizmie Boyle'a oraz iii) epistemologii izolowanych układów eksperymentalnych. Nawiązując do wielu opracowań z zakresu badań nad kształtowaniem się początków nauki nowożytnej, Kazibut podkreśla wpływ Boyle'a na zmiany w stylu uprawiania filozofii przyrody. Pisze, że dotychczasowe spekulatywne rozważania zostały zastąpione refleksją opartą na wynikach prac eksperymentalnych:

Uważam, że w efekcie tego zwrotu wytworzył się w dziejach filozofii przyrody nowy typ postawy badawczej. Była to synteza stylu związanego zakresowo z filozoficzną refleksją nad przyrodą (także w nawiązaniu do tradycji arystotelesowskiej) z filozofią naturalną, ujmowaną jako protonaukowa działalność przyrodoznawcza. W wyniku tej syntezy wyłoniła się filozofia przyrodoznawstwa, która miała być refleksją nad przyrodą prowadzoną w nawiązaniu i na podstawie osiągnięć nauk szczegółowych. [...] Zmienił się zakres zainteresowań badawczych podejmowanych przez pokolenie nowych filozofów przyrody. Tradycyjnie dominująca rola dociekań ontologicznych w filozofii przyrody straciła uprzywilejowane miejsce, wzrosło znaczenie problematyki metodologicznej i epistemologicznej (Kazibut 2019: 88-89). 
Za podstawową regułę metodologiczną Boyle uznawał zasadę intersubiektywnej sprawdzalności. Eksperymentowanie oznaczało dla niego głównie możliwość budowania izolowanych układów eksperymentalnych. Korzystając z nich, można manipulować przedmiotem badań i dzięki temu ustalać występujące podczas eksperymentowania związki przyczynowo-skutkowe.

W rozdziale drugim pt. Charakterystyka nauki laboratoryjnej zostały przedstawione wybrane filozoficzne koncepcje współczesnej nauki laboratoryjnej ze szczególnym uwzględnieniem jej specyficznych aspektów epistemologicznych i metodologicznych. Nauka laboratoryjna jako dominujący rodzaj praktyki badawczej została wyraźnie odróżniona od innego rodzaju działalności badawczej, jakim jest teoretyzowanie. Drugi rozdział obejmuje pięć części. Są w nich kolejno analizowane następujące zagadnienia: 1) struktura sytuacji eksperymentalnej i taksonomia składników nauki laboratoryjnej, 2) stabilność i doskonalenie się praktyki laboratoryjnej, 3) prymat eksperymentalizmu, który charakteryzuje się manipulowaniem, kreowaniem i konstruowaniem zjawisk, 4) realizm laboratoryjny, konstruktywizm i poietyczny charakter nauki laboratoryjnej oraz 5) aspekt epistemiczno-wykonawczy nauki laboratoryjnej. Omawiając te zagadnienia, Kazibut odwołuje się do ustaleń filozofów nauki (np. Iana Hackinga, Hasoka Changa, Danuty Sobczyńskiej czy Pawła Zeidlera) i prac socjologów, w tym również do przedstawicieli konstruktywizmu (Karin Knorr-Cetiny, Bruno Latoura). Nauki laboratoryjne zostają, zgodnie z propozycją Hackinga, określone jako te, w których działalność polega przede wszystkim na tworzeniu i wykorzystywaniu izolowanych układów eksperymentalnych. W ramach tych układów eksperymentatorzy wytwarzają zjawiska, które poza laboratorium nie występują. Na strukturę sytuacji eksperymentalnej składa się względnie stały zbiór czynników intelektualnych i materialnych, których wspólistnienie warunkuje i określa sposób eksperymentowania w nauce. Dokładną taksonomię tych czynników Kazibut przedstawia na podstawie prac Hackinga i Sobczyńskiej (Kazibut 2019: 112-114).

W podrozdziale dotyczącym zagadnienia stabilności i doskonalenia się praktyki laboratoryjnej głównym przedmiotem rozważań są ustalenia przedstawione przez Hackinga. Zostaje on wskazany jako ten badacz, który kwestionuje antykumulatywistyczny charakter rozwoju nauk laboratoryjnych. Broniąc tezy o stabilności rozwoju praktyki badawczej nauki laboratoryjnej, uznaje, że struktura tej praktyki jest wewnętrznie spójną konstrukcją, w której zachodzą procesy samoregulacji (Kazibut 2019: 114).

W podrozdziale poświęconym eksperymentalizmowi Kazibut bardzo zdecydowanie podkreśla prymat procedur badawczych związanych z eksperymentowaniem (manipulowanie, kreowanie, konstruowanie) nad procedurami o charakterze teoretycznym. Aby uzasadnić swoje stanowisko, odwołuje się do 
laboratoryjnej praktyki badawczej z zakresu chemii. Przywołuje analizy naukometryczne Joachima Schummera, które

wykazały, że w dziejach chemii obserwowany jest proces systematycznego i wykładniczego wzrostu liczby prac poświęconych syntezie nowych substancji chemicznych. Wnioski, jakie płyną z tych badań, uzasadniają przekonanie, że celem praktyki laboratoryjnej - w szczególności chemii - jest syntetyzowanie i analizowanie nowych substancji, a nie budowanie systematycznych teorii. Dlatego też chemia doskonale spełnia hackingowskie kryterium określone dla nauki laboratoryjnej (Kazibut 2019: 121).

Podrozdział omawiający zagadnienia realizmu laboratoryjnego, konstruktywizmu i poietycznego charakteru nauki laboratoryjnej otwiera charakterystyka realizmu zaproponowanego przez Hackinga. Kazibut przypomina, że jest to taki rodzaj realizmu, w którym zakłada się istnienie przedmiotów teoretycznych, kwestionując jednocześnie możliwość formułowania prawdziwych teorii dotyczących tych przedmiotów. Przedmioty teoretyczne istnieją, ponieważ można nimi, jak twierdzi Hacking, manipulować w trakcie prowadzenia prac eksperymentalnych. Manipulacyjne kryterium istnienia, które Hacking zaproponował dla praktyki laboratoryjnej fizyków, Kazibut analizuje w odniesieniu do praktyki laboratoryjnej charakterystycznej dla chemii. Odwołując się do prac Zeidlera i Sobczyńskiej, pisze, że kryterium to obowiązuje również w laboratorium chemicznym, ale należy je ujmować w pewnej relatywizacji do praktyki eksperymentalnej. $Z$ kolei laboratorium $w$ ujęciu konstruktywistów jest w większym stopniu warsztatem kreującym świat niż miejscem powielania bytów, które istnieją poza laboratorium (Kazibut 2019: 127). Konstruktywistyczne podejście do analizy procesów praktyki badawczej koresponduje, zdaniem autora, z obserwowaną od dłuższego czasu w humanistyce tendencją określaną jako zwrot performatywny, który należy rozumieć jako zainteresowanie specyficznym rodzajem sprawczości:

Dla tak ujmowanej performatywności praktyka laboratoryjna jest doskonałym przykładem. Poietyczny charakter eksperymentalizmu laboratoryjnego i niezwykła technologiczna innowacyjność wynikająca z osiągnięć nauk laboratoryjnych decyduje o tym, że wytwory tej aktywności naukowej są doskonałymi narzędziami umożliwiającymi zmienianie świata (Kazibut 2019: 129).

Podrozdział dotyczący aspektu epistemiczno-wykonawczego nauki laboratoryjnej poświęcony jest analizom prowadzonym głównie z punktu widzenia rozważań zaczerpniętych z prac Sobczyńskiej i Changa. Kazibut przychyla się bardziej do pierwszej z tych propozycji, ponieważ uważa, że podkreśla ona konieczność zachowania równowagi w opisie praktyki laboratoryjnej między wszystkimi jej komponentami, tj. zarówno tymi o charakterze podmiotowym, jak i przedmiotowym. Chang skupia się natomiast w zasadzie na podmiotowej grupie komponentów: 
istotną cechą eksperymentalizmu laboratoryjnego jest uzupełnianie się płaszczyzn: podmiotowej w aspekcie epistemicznym i wykonawczym z materialno-techniczną. Ich połączenie decyduje, między innymi, o tym, że jest to praktyka badawcza, która wyróżnia się na tle przyrodoznawstwa. Nie można jej analizować, zakładając pozytywistyczny sposób rozumienia, czym jest uprawianie nauki, gdyż z tej perspektywy nie można uchwycić epistemiczno-wykonawczej płaszczyzny działalności laboratoryjnej (Kazibut 2019: 139).

W trzecim, najbardziej autorskim, rozdziale pracy pt. Przekonania filozoficzne $w$ nauce Kazibut przedstawia propozycję usystematyzowania przekonań filozoficznych występujących w nauce. Pisząc o ich roli, podkreśla, że interesuje go nie tyle historyczny aspekt tego zagadnienia, ile współczesne spojrzenie, które zakłada, że „przekonania filozoficzne są ważnym elementem wpływającym na kształt poznania od zarania nauki aż po czasy współczesne” (Kazibut 2019: 144). Punktem wyjścia rozważań jest sformułowana przez Kazimierza Jodkowskiego koncepcja epistemicznego układu odniesienia (EUO), w ramach której zwraca się uwagę na obecność zbioru przekonań filozoficznych w procesie rozwoju wiedzy naukowej. Zbiór takich przekonań jest akceptowany przez badaczy:

Stanowi on o sile potencjału światopoglądowo-twórczego, który ujawnia się wraz z działalnością przyrodoznawców i za sprawą technicznych aplikacji rezultatów prac badawczych (Kazibut 2019: 141).

Nawiązując do prac Henryka Mehlberga i Zygmunta Zawirskiego, Kazibut w zbiorze przekonań filozoficznych obecnych w nauce wyróżnia zarówno presupozycje filozoficzne, jak i założenia filozoficzne. Pierwsze nazywa przekonaniami przenikającymi do przyrodoznawstwa spoza nauki, a drugie traktuje jako tezy uznawane na podstawie twierdzeń przyrodoznawczych:

Presupozycje filozoficzne przyjmowane przez badaczy są w znacznym stopniu tożsame z przekonaniami filozoficznymi akceptowanymi w ich kolektywach badawczych i wspólnotach kulturowych. Zawsze mają charakter pozanaukowy i pozaempiryczny. Natomiast założenia filozoficzne określa się na podstawie zbioru uznawanych zdań w nauce i są pośrednio sprawdzalne za sprawą odwołania się do rezultatów prac badawczych. Przyjęcie danego założenia filozoficznego oparte jest na racjonalnym przekonaniu, że można je zaakceptować w świetle zbioru zdań sprawdzalnych w nauce. Różnica pomiędzy presupozycją filozoficzną a założeniem filozoficznym polega na tym, że ta pierwsza przyjmowana jest na drodze tylko apriorycznej i spekulacyjnej, a założenie filozoficzne również na podstawie aposteriorycznej (Kazibut 2019: 142-143).

Na podstawie ustaleń Mehlberga i Zawirskiego Kazibut stawia tezę, że skonstruowanie naukowego obrazu świata przyrody wymaga przyjęcia określonego rodzaju systemu założeń i presupozycji filozoficznych:

W związku z tym w filozoficznej refleksji nad przyrodą i przyrodoznawstwem musi być brane pod uwagę to, w jaki sposób uprawiana jest nauka i dostarczane przez nią rezul- 
taty poznawcze. Rozwój nauki może być opisywany między innymi jako proces nieprzerwanego przepływu idei filozoficznych z i do przyrodoznawstwa. Kwestią, która pozostaje do rozstrzygnięcia, jest określenie natury tej zależności. Zwolennicy istnienia więzi pomiędzy filozofią a przyrodoznawstwem są skłonni nadawać temu związkowi charakter symetryczny. Przykładem takiego podejścia jest badawcza aktywność Roberta Boyle’a, którego poglądy przyrodoznawcze i filozoficzne kształtowały się za sprawą ścisłego połączenia obu tych obszarów ludzkiej działalności (Kazibut 2019: 151).

W podrozdziale dotyczącym zależności między presupozycjami filozoficznymi a założeniami filozoficznymi Kazibut rozbudowuje swoje wcześniejsze ustalenia. Dołącza do nich rozważania Robina G. Collingwooda, według którego we wszystkich procesach intelektualnych istotną rolę odgrywają przyjmowane przez ludzi przekonania - założenia bądź presupozycje. Między założeniami a presupozycjami zachodzi związek: każdemu założeniu towarzyszy jakaś supozycja, na przykład supozycją jest to, że każde założenie, w zależności od sytuacji, może zostać zastąpione innym. Ponadto wszystkie założenia są presupozycjami, ale nie wszystkie presupozycje są założeniami (Kazibut 2019: 152). Kazibut podkreśla, że zarówno Collingwood, Jodkowski, Mehlberg, jak i Zawirski przypisują znaczącą rolę $w$ rozwoju nauki szeroko rozumianym filozoficznym przekonaniom towarzyszącym nauce. Przyznaje, że naukowcy często nie wiedzą o przyjmowanych przez siebie filozoficznych założeniach i presupozycjach. Ich ujawnieniem zajmują się filozofowie, metodolodzy nauki, filozofowie przyrody, historycy oraz socjologowie nauki (Kazibut 2019: 155-156).

W czwartym rozdziale pt. Wkład Roberta Boyle'a $w$ powstanie nauki laboratoryjnej Kazibut wykorzystuje przyjęte wcześniej ustalenia do zrekonstruowania tez epistemologii Boyle'a. Przekonuje, że epistemologię angielskiego badacza należy określić mianem epistemologii eksperymentalistycznej, czyli takiego stanowiska filozoficznego, zgodnie z którym głównym narzędziem w poznaniu naukowym jest metoda eksperymentalna.

Na rozdział czwarty składają się cztery podrozdziały: 1) eksperymentalizm Boyle'a a początki praktyki badawczej nauki laboratoryjnej, 2) system filozoficzno-przyrodoznawczy Boyle'a a początki nowożytnego przyrodoznawstwa, 3) problem obiektywności poznania a laboratoryjny styl badawczy Boyle'a, 4) system filozoficzno-przyrodoznawczy Boyle'a a geneza nauk baconowskich. Omawiając epistemologię eksperymentalistyczną Boyle'a, Kazibut stwierdza, że konstytuują ją dwa przekonania na temat wiedzy. Pierwsze zakłada, że wiedza naukowa ma charakter wiedzy o faktach, które są ustalane na podstawie wyników przeprowadzanych eksperymentów, drugie natomiast, że otrzymana tą drogą wiedza może być sprawdzana przez stosowanie metody eksperymentalnej: 
Nadbudowany nad stanowiskiem epistemologii eksperymentalistycznej laboratoryjny styl badawczy Boyle'a wpłynął na początki kształtowania się praktyki badawczej nowożytnej nauki laboratoryjnej. W wyniku filozoficznej i naukowej działalności Boyle'a przednaukowa praktyka alchemików i rzemieślników została zaadaptowana na potrzeby nowożytnego stylu badań laboratoryjnych. W ten sposób Boyle nie tylko przyczynił się do powstania laboratoryjnego przyrodoznawstwa, ale przede wszystkim osiągną to, że utylitaryzm został uznany za autoteliczną wartość nauki (Kazibut 2019: 160).

W podrozdziale poświęconym systemowi filozoficzno-przyrodoznawczemu Boyle'a i początkom nowożytnego przyrodoznawstwa Kazibut przekonuje, że system ten był podstawą, na której dokonało się przekształcenie przednaukowego stylu laboratoryjnego w naukową praktykę laboratoryjną:

Rozwój laboratoryjnego stylu badawczego stanowił etap pośredni pomiędzy przedlaboratoryjnym stylem pracy alchemików i rzemieślników a ukształtowaniem się dojrzałej nowożytnej praktyki badawczej nauki laboratoryjnej. Przyjmowane przez Boyle'a rozstrzygnięcia metodologiczne i epistemologiczne spowodowały, że praktyka laboratoryjna została oparta na racjonalnie uzasadnionych metodologicznych podstawach (Kazibut 2019: 168).

Kazibut uważa, że główną presupozycją filozoficzną, na której Boyle oparł swój system filozoficzno-przyrodoznawczy, był naturalizm metodologiczny. Podzielali go wszyscy wybitni siedemnastowieczni badacze, którzy odegrali decydującą rolę $\mathrm{w}$ ukształtowaniu się nowożytnego paradygmatu poznania naukowego.

Podrozdział o problemie obiektywności poznania i laboratoryjnym stylu badawczym Boyle'a rozpoczyna się od przypomnienia zasadniczej roli izolowanych układów eksperymentalnych w udoskonalaniu praktyki badawczej nowożytnych nauk przyrodniczych. Kazibut podkreśla, ze Boyle był jednym z pierwszych badaczy, którzy doceniali wagę wykorzystania takich układów w badaniach przyrodniczych i że to właśnie on rozpoczął prace nad rozwijaniem ich metodologii (Kazibut 2019: 176).

W części poświęconej ukazaniu systemu filozoficzno-przyrodoznawczego Boyle'a w kontekście genezy nauk baconowskich Kazibut kładzie nacisk na dokonania angielskiego badacza w zakresie promowania wiedzy praktycznej. Boyle powiązał wiedzę wytwarzaną $\mathrm{w}$ praktyce $\mathrm{z}$ wiedzą naukową:

Dla potrzeb laboratoryjnego stylu prowadzenia badań naukowych Boyle założył, że wiedza naukowa jest tworzona przez działanie, a głównym jego narzędziem jest eksperymentowanie. Boyle wiedzę wytworzoną w badaniach laboratoryjnych interpretował na gruncie swojego systemu filozoficzno-przyrodoznawczego. Dla niego wytwarzanie wiedzy w laboratorium nie było tylko wypadkową zręczności i pomysłowości człowieka, ale wymagało przyjęcia określonej postawy filozoficznej (Kazibut 2019: 178). 
W Zakończeniu autor raz jeszcze skrótowo omawia swoje rozważania, które przedstawił w czterech rozdziałach książki. Podkreśla osiągnięcia badawcze Boyle'a. Pisze, że zbudował on swój system filozoficzno-przyrodniczy w taki sposób, iż

mógł włączyć w obszar nauki wiedzę praktyczną, której wartość była oceniana sceptycznie przez jemu współczesnych. W jego epistemicznym układzie odniesienia niedowartościowana wiedza wytwarzana w praktyce mogła zostać przeanalizowana w nowym filozoficznym kontekście. Umożliwiło to wykazanie, że jest to wiedza wartościowa zarówno ze względu na cele poznawcze nauki, jak i stawiane przed nią utylitarne zadania. Zdecydowało to o sposobie, w jaki potoczyła się naukowa rewolucja w XVII stuleciu. Ważnym dokonaniem Boyle’a było także to, iż uświadomił społeczności naukowej, że $\mathrm{w}$ pracach laboratoryjnych należy kierować się ściśle określonym zbiorem zasad (Kazibut 2019: 183).

Uważam, że na uznanie zasługuje główny cel rozważań Kazibuta - by na przykładzie konstytuowania się filozofii przyrody i przyrodoznawstwa Roberta Boyle'a przedstawić problem zależności między filozofią a nauką. Na temat tych zależności powstało wprawdzie wiele opracowań, żadne z nich nie skupia się jednak na analizie zagadnienia filozoficznej genezy nauki laboratoryjnej. Kazibut próbuje to zagadnienie postawić i zbadać. Wnioski, które przedstawia, są przekonujące. Wynika z nich, że opierając się na pracach Boyle'a, można pokazać, iż założone $\mathrm{w}$ nich rozstrzygnięcia filozoficzne ukształtowały postawy epistemologiczne, które umożliwiły powstanie laboratoryjnego stylu badań naukowych. Styl ten wpłynął na proces rozwoju nauki nowożytnej i w dużym stopniu przyczynił się do sformułowania współczesnego modelu nauki laboratoryjnej.

$\mathrm{Na}$ pozytywną ocenę zasługuje również sposób realizacji założonego w monografii celu. Kazibut analizuje zarówno teksty samego Boyle'a, jak i prace współczesnych badaczy jego twórczości. Pisząc o zależnościach między filozofią a nauką, wykorzystuje głównie ustalenia, które czerpie z lektury polskich filozofów. Dużo uwagi poświęca rozważaniom Mehlberga, Zawirskiego, Sobczyńskiej, Jodkowskiego i Zeidlera. Rozważania autora są wyrażone za pomocą jasnego i wyraźnego języka, który jest solidnie ugruntowany w dyskursie humanistycznym.

Ogólnie pozytywna ocena książki Kazibuta nie oznacza jednak, że nie należy skierować pod jej adresem pewnych uwag krytycznych. Chciałbym zasygnalizować kilka z nich. Dotyczą one przede wszystkim nieuwzględnienia przez autora pewnych zagadnień, które w kontekście analizowanych w pracy kwestii uznać należy za ważne. Rozumiem, że literatura związana z omawianym $\mathrm{w}$ rozprawie tematem jest bardzo obszerna i przedstawienie jej w całości byłoby niemożliwe, zbędne, a nawet kontrproduktywne. Uważam jednak, że pożądane 
byłoby uwzględnienie poglądu na genezę nauki nowożytnej wyrażonego przez Johna Watkinsa. Mam na myśli głównie wątki historyczno-teoretyczne, a zwłaszcza ten dotyczący tzw. „Ideału Bacona-Kartezjusza” (Watkins 1989: 35). Wspominane w kilku miejscach przez autora przeplatanie się aspektów teoretycznych i eksperymentalnych w myśli Boyle'a warto byłoby odnieść do propozycji, o której pisze Watkins.

Kazibut pisze o pracy Boyle'a The Sceptical Chymist jako symbolicznym słupie Herkulesa, po którego przekroczeniu rozpoczął się nie tylko proces kształtowania nowożytnej chemii, lecz także proces ksztaltowania laboratoryjnej praktyki badawczej. Warto w tym kontekście wspomnieć o roli, którą w kształtowaniu tego drugiego procesu odegrał Robert Hooke. Analizując filozofię eksperymentu, Ian Hacking określa Boyle’a mianem „teoretyka, który eksperymentowal”, Hooke'a nazywa natomiast „eksperymentatorem, który także teoretyzowal" (Hacking 1983: 150-151). Warto wspomnieć też o ścisłej współpracy Boyle'a i Hooke’a. Jej efektem było między innymi udoskonalenie, skonstruowanej przez Ottona von Guerickego, pompy próżniowej, którą obydwaj angielscy badacze intensywnie wykorzystywali w prowadzonych przez siebie pracach eksperymentalnych.

Bardzo ważna dla konstrukcji całej pracy jest wywiedziona od Jodkowskiego koncepcja epistemicznego układu odniesienia (EUO). Uważam, że nie mniej interesującą i wartą przywołania koncepcją, która pozwala na przeprowadzenie głębokiej interpretacji problemu zależności między nauką a filozofią w kontekście ksztaltowania się nauki nowożytnej, jest Stefana Amsterdamskiego koncepcja ideału wiedzy naukowej (Amsterdamski 1983). W ramach rzeczywistej działalności badawczej ideały wiedzy naukowej, pisze Amsterdamski, pełnią określone funkcje. Po pierwsze, ,wyznaczają potencjalne granice zjawiska zwanego nauką”. Po drugie, „stanowią filtr, który sprawia, że jedne problemy badawcze możliwe do podjęcia w danej sytuacji poznawczej zostają zakwalifikowane jako godne badania, interesujące czy ważne, inne zaś mogą zostać niedostrzeżone lub pominięte jako nieistotne czy zgoła nienaukowe”. Po trzecie, „wraz z akceptowanymi przekonaniami ontologicznymi i epistemologicznymi współwyznaczają reguły akceptacji twierdzeń i ich odrzucania, zasady zadowalającego wyjaśniania zjawisk, sposoby budowania teorii - jednym słowem, reguły metodologiczne badan”. Po czwarte wreszcie, „implikują określony etos naukowy i wewnętrzną organizację społeczności uczonych, ich rozumienie nauki jako instytucji społecznej” (Amsterdamski 1983: 32-40). Po scharakteryzowaniu kategorii ideału wiedzy naukowej Amsterdamski pisze wprost o nowożytnym ideale nauki. Szczególnie ważne wydają się jego krytyczne uwagi na temat badaczy, którzy tłumacząc powstanie nauki nowożytnej, twierdzili, że „zrodziła się ona z porzucenia filozoficznej spekulacji i uznania 
autorytetu doświadczenia, empirii”. Interesujące w kontekście rozważań przedstawionych w książce Kazibuta są też uwagi Amsterdamskiego dotyczące tego, w jaki sposób Newton doszedł do sformułowania swojej głośnej tezy: hypothesis non fingo.

Kazibut często podkreśla utylitarny aspekt eksperymentalizmu Boyle'a. Łączy go z dążeniem angielskiego badacza do wypracowania swoistego wzorca, który byłby filozoficznym zapleczem prac laboratoryjnych prowadzonych przez kolejne pokolenia eksperymentalistów. W ramach takiego wzorca znalazły się następujące wartości: skrupulatność, precyzja, systematyczność, ostrożność, krytycyzm, obiektywizm, pluralizm metodologiczny, zasada intersubiektywnej komunikowalności i sprawdzalności wiedzy, eksperymentalizm oraz naturalizm metodologiczny (Kazibut 2019: 183). Przy zestawieniu utylitaryzmu z tym, co Kazibut, sięgając do pism Boyle'a, nazywa etosem badacza eksperymentalisty, pojawia się wątpliwość, czy dążenie do sukcesów utylitarnych pozostaje zbieżne z tym etosem. Dla samego Boyle’a i współczesnych mu badaczy wiedza laboratoryjna dostarczać miała informacji o świecie. Informacje te mogą być ewentualnie wykorzystane praktycznie, ale nie na tym polega ich główna wartość. Warto pamiętać, że z kategorią użyteczności jest problem, o którym wspominał już Kartezjusz - co dla jednych jest użyteczne, dla innych może być szkodliwe.

Omawiając aspekt epistemiczno-wykonawczy nauki laboratoryjnej, Kazibut pisze:

Działalność laboratoryjna nie jest tylko pracą badawczą nastawioną na poznawanie i gromadzenie wiedzy o świecie przyrody, ale jest również nakierowana na realizowanie zadania polegającego na podporządkowywaniu go człowiekowi (Kazibut 2019: 139).

W kontekście tego typu stwierdzeń, a pojawiają się one w pracy często, brakuje filozoficznej refleksji nad społeczną odpowiedzialnością otrzymywanych w trakcie działalności laboratoryjnej wytworów, które mają za zadanie podporządkowywanie świata człowiekowi. Wytwory te przecież często przyczyniają się do zmiany świata. Ich moc oddziaływania sprawia, że rozpoznanie skutków tego oddziaływania staje się, jak pisze Hans Jonas, drugą stroną obowiązku naszej wiedzy (Jonas 1996) oraz istotną częścią analizy związanej coraz bardziej z koniecznością samokontroli ideału, który w nawiązaniu do jednego z aforyzmów Bacona można by nazwać ideałem naukowo-technicznej potęgi. Zgodnie z tym ideałem podstawowym zadaniem badawczym uczonych jest dostarczanie wiedzy i technologii dla ekonomicznego i przemysłowego rozwoju społeczeństwa (Krimsky 2006: 265).

Analizując wywiedzioną z tradycji zapoczątkowanej przez Bacona i Boyle'a współczesną wersję laboratoryjnej praktyki badawczej, szczególnie tę z zakresu 
nauk chemicznych, Kazibut całkowicie pomija wiele ważnych pytań metanaukowych. Tymczasem warto zwrócić uwagę przynajmniej na niektóre z nich. Stawia je między innymi Roald Hoffmann, wprost pytając, czy chemicy interesują się przedmiotami swoich badań ze względów czysto poznawczych, czy też o wyborze tych przedmiotów rozstrzygają inspiracje innego rodzaju, na przykład te związane z rozwojem przemysłu; czy chemia wywołuje skutki społecznie pożądane, czy też społecznie niepożądane; czy ocena tych skutków jest subiektywna, czy też obiektywna (Hoffmann 1995). W książce Kazibuta nie ma w ogóle tego typu rozważań.

Drugi rozdział monografii jest poświęcony, jak widzieliśmy, charakterystyce nauki laboratoryjnej. Kazibut przybliża głównie to jej ujęcie, które wywodzi się z prac przedstawicieli „nowego eksperymentalizmu”. Wspomina także o propozycji przedstawicieli konstruktywizmu. W obu tych przypadkach akcentowane są te cechy nauki laboratoryjnej, które wiążą się z wytwarzaniem nowych zjawisk. W książce pominięte zostaje natomiast zasadniczo odmienne ujęcie nauki laboratoryjnej, to mianowicie, które zaproponował w swojej koncepcji realizmu transcendentalnego Roy Bhaskar. Według niego podstawowy cel nauk laboratoryjnych sprowadza się nie do wytwarzania nowych zjawisk, lecz do badania i wykrywania generatywnych mechanizmów natury, które rządzą przebiegiem rzeczywistych zjawisk. Mechanizmy te Bhaskar określa mianem nieprzechodnich przedmiotów wiedzy. Uznaje, że ich poznanie jest możliwe jedynie w sztucznym środowisku, tj. takim, które zostaje wytworzone $\mathrm{w}$ laboratorium. Ze względu na możliwość tworzenia w laboratorium izolowanych systemów zamkniętych eksperymentatorzy potrafią odkrywać obiektywne prawa nauki. Praw tych nie można natomiast odkryć w systemach otwartych, w których różne prawa wzajemnie na siebie wpływają i przez to działanie jednych zakłócane jest przez działanie innych (Bhaskar 2008: 46-52). Dla Bhaskara laboratorium pozostaje zatem miejscem, w którym uczeni formułują obiektywne prawa nauki. Prawa te mają zastosowanie $\mathrm{w}$ różnych dziedzinach ludzkiej działalności.

Na zakończenie swoich uwag chciałbym raz jeszcze podkreślić, że książka Kazibuta jest przede wszystkim interesującym głosem w dyskusji o zależnościach między filozofią a nauką. Autor opisuje je z punktu widzenia genezy nauki laboratoryjnej. Charakteryzując jej początki, zwraca głównie uwagę na rolę eksperymentowania i wytwarzania wiedzy naukowej w praktyce, standaryzację procedur badawczych oraz systematyczne doskonalenie instrumentarium badawczego. Swoje rozważania opiera na lekturze pism Boyle'a. Wywodzi z nich przekonanie o potrzebie autonomii nauki względem filozofii. Dodaje, że nie jest to jednak pełna autonomia. Zakłada się w niej pewne presupozycje filozoficzne, które przyjmują postać epistemicznego układu odnie- 
sienia. W przypadku nowożytnych nauk przyrodniczych takim epistemicznym układem odniesienia jest m.in. naturalizm metodologiczny.

Oceniając monografię Kazibuta, warto ją zestawić z innymi pracami poświęconymi twórczości Boyle'a, których $\mathrm{w}$ ostatnich kilkudziesięciu latach powstało w światowej literaturze stosunkowo wiele. Opisują one dorobek autora The Sceptical Chymist z różnych perspektyw poznawczych. Jako przykład można podać książkę Stevena Shapina i Simona Schaffera Leviathan and the Air-Pump: Hobbes, Boyle, and the Experimental Life czy teksty Mariny P. Banchetti-Robino. W pierwszym przypadku Boyle zostaje przedstawiony zarówno jako inicjator eksperymentalizmu, jak i „uczony-obywatel”, który w poczuciu odpowiedzialności za życie publiczne dąży, za pomocą prac eksperymentalnych, do rozwiązywania konfliktów społecznych. Autorzy wykorzystują więc przykład Boyle’a, by pokazać zależności między nauką a jej społecznym uwarunkowaniem (Shapin, Schaffer 1985, Latour 2011). W drugim natomiast przypadku Boyle zostaje przedstawiony jako jeden z głównych pionierów badań chemicznych nad ontologicznym napięciem między witalizmem a mechanicyzmem oraz jako autor pojęcia pierwiastka chemicznego (Banchetti-Robino 2011, 2015).

Obydwie prace, mimo zasadniczo odmiennej tematyki, skupiają się na takiej prezentacji Boyle'a, w ramach której autorzy bardzo wyraźnie formułują cel badawczy swoich rozważań. Podobną strategię przyjął Kazibut, który, jak widzieliśmy, koncentruje się na „analizie wpływu filozoficznych idei Boyle’a na powstanie filozoficznego fundamentu nowożytnej i współczesnej nauki laboratoryjnej”. Takie wyraźne wyznaczenie podstawowego celu badań i związany z jego realizacją wybór wykorzystanej literatury pozwala odróżnić Filozofię przyrody i przyrodoznawstwa Roberta Boyle'a od innych prac poświęconych twórczości brytyjskiego chemika, które zostały dotychczas opublikowane $\mathrm{w}$ polskiej literaturze przedmiotu. Prace te mają głównie charakter historyczny. Zasadniczo sprowadzają się do charakterystyki naukowej działalności Boyle'a, wskazując na rolę, którą działalność ta odegrała w rozwoju szeroko ujętej nauki nowożytnej (Afeltoficz, Sojak 2015, Kucharski 2015, Pietrzak 2019) lub nowożytnej chemii (Sobczyńska 1984, Mierzecki 1987).

Moje zastrzeżenia $\mathrm{w}$ stosunku do rozważań zawartych $\mathrm{w}$ monografii Kazibuta dotyczą głównie pominięcia kilku zagadnień, które w kontekście analizowanych w niej kwestii należy uznać za ważne. Mam na myśli przede wszystkim zagadnienia związane z własnościami nauki laboratoryjnej. Przedstawiona w pracy jej charakterystyka jest w zbyt dużym stopniu wybiórcza. Pomija na przykład całkowicie problem niepożądanych wytworów nauki laboratoryjnej oraz kwestię jej coraz bardziej praktycznego charakteru. 


\section{BIBLIOGRAFIA}

Afeltowicz K., Sojak R. (2015), Arystokraci i rzemieślnicy. Synergia stylów badawczych, Torun: Wydawnictwo Naukowe UMK.

Amsterdamski S. (1983), Między historiq a metodą, Warszawa: Państwowy Instytut Wydawniczy.

Banchetti-Robino M. P. (2011), Ontological Tensions in Sixteenth and Seventeenth Century Chemistry: Between Mechanism and Vitalism, „Foundations of Chemistry” 13(3), 173-186. https://doi.org/10.1007/s10698-011-9126-9

Banchetti-Robino M. P. (2015), From Corpuscles to Elements: Chemical Ontologies from Van Helmont to Lavoisier [w:] Philosophy of Chemistry: Growth of a New Discipline, E. Scerri, L. McIntyre (eds.), Dordrecht: Springer, 141-154. https://doi.org/10.1007/ 978-94-017-9364-3_10

Bhaskar R. (2008), A Realistic Theory of Science, London-New York: Routledge.

Jonas H. (1996), Zasada odpowiedzialności. Etyka dla cywilizacji technologicznej, tłum. M. Klimowicz, Kraków: Platan.

Hacking I. (1983), Representing and Intervening: Introductory Topics in the Philosophy of Natural Science, Cambridge: Cambridge University Press. https://doi.org/10.1017/ CBO9780511814563

Hoffmann R. (1995), The Same and Not the Same, New York: Columbia University Press.

Kazibut R. (2019), Filozofia przyrody i przyrodoznawstwa Roberta Boyle'a. Filozoficzna geneza nauki laboratoryjnej, Poznań: Wydawnictwo Naukowe UAM.

Krimsky S. (2006), Nauka skorumpowana?, tłum. B. Biały, Warszawa: Państwowy Instytut Wydawniczy.

Kucharski D. (2015), Hobbesa krytyka metody eksperymentalnej Boyle'a, „IDEA - Studia nad strukturą i rozwojem pojęć filozoficznych”, XXVII, 241-253. https://doi.org/ 10.15290/idea.2015.27.t.t.14

Latour B. (2011), Nigdy nie byliśmy nowocześni. Studium z antropologï symetrycznej, tłum. M. Gdula, Warszawa: Oficyna Naukowa.

Mierzecki R. (1987), Historyczny rozwój pojęć chemicznych, Warszawa: Państwowe Wydawnictwo Naukowe.

Pietrzak Z. (2019), Spór o ontologię własności przyrody. Robert Boyle a perypatetycy, spagirycy i matematycy, „Studia z Historii Filozofii” 1(10), 141-168. https://doi.org/ 10.12775/szhf.2019.009

Shapin S., Schaffer S. (1985), Leviathan and the Air-Pump: Hobbes, Boyle, and Experimental Life, Princeton-Guildford: Princeton University Press.

Sobczyńska D. (1984), Osobliwości chemii, Poznań: Wydawnictwo Naukowe UAM.

Watkins J. (1989), Nauka a sceptycyzm, tłum. E. i A. Chmieleccy, Warszawa: Państwowe Wydawnictwo Naukowe. 